\title{
e-Tourism, Personal Technology Post-Adoption Behavior, and Sustainable Behavior Intention in Indonesia
}

\author{
Merinda Pandowo ${ }^{\mathrm{a}, *}$, Imelda W. J. Ogi ${ }^{\mathrm{a}}$, Claudia W. M. Korompis ${ }^{\mathrm{b}}$, Christoffel M. O. Mintardjo ${ }^{\mathrm{a}}$ \\ ${ }^{a}$ Management Dept, Faculty of Economics and Business, University of Sam Ratulangi, Manado \\ ${ }^{b}$ Accounting Dept, Faculty of Economics and Business, University of Sam Ratulangi, Manado
}

\begin{abstract}
e-tourism's behavior in minimizing the use of natural resources and costs gives birth to sustainable behavior in the form of environmentally friendly tourism and digital technology. This study aims to examine the effects of technology-based post-adoption behavior by tourists that lead to sustainable behavior. Predictors of technology usage using some of the UTAUT2 models. The survey was conducted in Indonesia on respondents in Manado, who obtained as many as 100 participants, which were then analyzed using path analysis. The research findings show that the UTAUT2 model, namely the relationship between hedonic motivation, price value, and habit, affects sustainable behavior mediated by behavior intention. These findings contribute to the development of technology-based marketing and tourism management.
\end{abstract}

Keywords: e-tourism, personal technology, post-adoption, sustainable behavior, hedonic motivation

\section{INTRODUCTION}

The tourism industry is currently one of the most important industries driving the global economy (Guerreiro, 2019). Despite being impacted by the COVID-19 pandemic in 2020 (Haryanto, 2020), the tourist sector began to recover slowly by the end of 2021 (UNWTO, 2021), and it is expected that when the pandemic is over, tourism will rebound and become the key driver of the global economy (Babii and Nadeem, 2021).

Changes in tourist tastes, the creation of a new middle class from the millennial and gen-z generations (Kurniawan et al., 2021), as well as technological advances, namely digital technology (Akhtar et al., 2021), have all contributed to the resurgence of the tourism sector following COVID-19 (Gretzel et al., 2020). E-tourism is a digital technology platform that contains large amounts of data about tourism, news, events, locations, and ravel, as well as transportation and lodging, that can be personalized by travelers (Nugraheni and Nurhaeni, 2018).

The growth of e-tourism is aided by the development of sustainable behavior. Global consumer awareness of the need for environmentally friendly conduct has led to the rise of etourism based on sustainable behavior (Bergin-Seers and Mair,

\footnotetext{
*Author in correspondence,

Email address: merindapandowo@unsrat .ac.id (Merinda Pandowo)
}

ISSN: 2549-3221 (Print) 2549-323X (Online)

DOI: $10.26487 /$ hebr.v5i3.3411
2009), The topic of global climate challenges, notably the incidence of climate change and global warming, has prompted this ecologically responsible conduct (Friedman, 2017). Tourists, as tourist consumers, are becoming increasingly conscious that their actions influence the natural environment, particularly in terms of the products and services they buy, whether directly or indirectly.

This technology-based tourist knowledge and action for sustainable behavior may also be seen in poor nations, such as Indonesia (Mihanyar et al., 2015); (Nelson et al., 2021). The tourism profile and local wisdom of tourist destinations in Indonesia based on nature tourism or ecotourism are also supported by the sustainable conduct of visitors visiting tourist sites in Indonesia, both international and domestic (Burhanudin and Unnithan, 2021).

This study was based on Nanggong (2018) which examined the UTAUT2 model for post-technology adoption behavior with 162 respondents in a previous study. The findings reveal that hedonic incentives, price value, and habits impact technology adoption intentions, but perceived advantages have little effect on the link between deliberate conduct and long-term behavior. Nanggong and Rahmatia (2019) conducted a study on eticket consumers with 188 participants. The results reveal that perceived benefits and contextual factors influence long-term customer behavior when it comes to technology adoption. The focus on the tourist industry, namely the adoption of e-tourism technologies, is the key distinction between the two studies and this research. 
The fundamental goal of this study, as stated above, is to look at the post-technology adoption behavior of e-tourism in Indonesia. The UTAUT2 model is used in this study to look at the interaction between hedonic motivation (HM), price value (PV), and habit $(\mathrm{H})$ on sustainable behavior (SB) with behavioral intention (BI) as a mediator, specifically in Indonesian etourism behavior.

\section{LITERATURE REVIEW}

\section{1. e-Tourism}

e-Tourism reflects the digitization of all processes and value chains in the tourism industry, such as travel agents, hospitality, and catering. Tactically, e-tourism includes e-commerce and uses information and communication technology (ICT) to maximize the efficiency and effectiveness of the tourism business (Jonathan and Tarigan, 2016). At a strategic level, E-Tourism revolutionizes all business processes, the entire value chain, and the strategic relationships of tourism organizations with all stakeholders.

Kotler and Bowen (2016) explain that e-tourism is a technology used for tourism activities and helps companies engaged in tourism services increase their business and improve the know-ledge-sharing process. E-Tourism utilizes several features of information technology in its development, namely: tourism in-formation databases, user databases, electronic payments, and using the internet network as a means of shipping and service transactions (Zhang, 2009).

\subsection{Technology Adoption}

Technology adoption and diffusion behavior refer to the Theory of Reasoned Action (TRA) developed by Fishbein and Ajzen (1972), which explains that what determines individual behav-ior is an individual's intention, which is jointly influenced by individual attitudes and subjective norms (Fishbein and Ajzen, 2015). Then came another refinement by Ajzen (1991), namely the Theory of Planned Behavior (TPB), which included per-ceived behavioral control as the third determinant of individual behavior when they wanted to use technology. In 1989, Davis (1989) adapted TRA to develop a technology acceptance model (TAM). This model defines perceived ease of use and perceived usefulness as two determinants of attitudes towards intentional behavior and use.

Venkatesh et al. (2003) review and synthesize a framework that leads to a unified view of technology acceptance by comparing eight models that have similarities, namely Theory of Reasoned Action (TRA), Technology Acceptance Model (TAM), Motivational Model (MM), Theory of Planned Behavior (TPB), Combined (CTAM TPB), Model of PC Utilization (MPCU), Innovation Diffusion Theory (IDT), and Social Cognitive The-ory (SCT), resulting in a formulation called the Unified Theory of Acceptance and Use of Technology (UTAUT) with four key predictors of technology use intention, namely performance, ef-fort expectancy, social influence, and facilitating conditions.

\subsection{Sustainable Behavior}

Based on the view of ABC (attitude behavioral context), explains that behavior is the interactive result of personal attitudes and contextual factors (Kostadinova, 2016). Sustainable behavior as a study motivated by social and environmental considerations has become an important topic in public policy and consumer psychology (Luchs and Mooradian, 2012). According to Tapia Fonllem et al. (2013), sustainable behavior is an action that aims to protect the natural and social environment. The term sustainable behavior in practice has similarities with pro-environmental behavior.

Sustainable behavior in the psychological perspective is defined as a collection of actions aimed at protecting the sociophysical resources of this planet (Gifford, 2007). Although sustainable behavior has the same terms as pro-environmental behavior, the last term refers to efforts to protect the natural environment, while sustainable behavior is more specifically emphasized on efforts to protect both the natural environment and the human (social) environment (Tapia Fonllem et al., 2013).

\subsection{Behavioral Intention}

The term behavioral intention is widely used in the technology acceptance and use literature. Intentional behavior is interpreted as the perception of the possibility that someone will use technology. In another study, Bhattacherjee (2001) used continuance intention to understand IT acceptance and user behavior. This model describes when information technology adopters get satisfaction, and continuance intention will occur. However, according to Aria and Archer (2014), the constructs of continuance intention and behavioral intention have a commensurate meaning to test whether users continue to use technology for a long time. Based on these arguments, this study will use the term behavioral intention.

\subsection{Hedonic Motivation}

Hedonic motivation is the joy or pleasure obtained from using technology and plays an important role in determining the acceptance and use of technology (Brown and Venkatesh, 2005). Users expect pleasure and comfort when adopting a mobile phone to obtain information and services (Alwahaishi and Snasel, 2013). When these expectations are achieved, consumers will continue to use the technology. This hedonic motivation follows the explanation of the IT continuance model that there is satisfaction experienced by technology adopters resulting in continuance intention or, in other words, there is a desire to continue using the technology.

\subsection{Price Value}

Price value means costs and price structures that may significantly impact consumers using technology (Nguyen et al., 2014). Costs and prices will have an impact on the use of technology by consumers. The value of prices and costs in the context of consumer users (individuals) and organizations is different because consumers will usually bear the monetary costs of using technology (Venkates et al., 2012). Furthermore, the price will positively affect intentions when consumers feel the 
benefits of using technology are more significant than the monetary costs incurred. Arenas-Gaitan et al. (2015) also show that the value of the price affects the intention of technology adoption. Therefore, the suitability of the price value will determine the behavior of a person's intention to adopt the technology.

\subsection{Habits}

Previous studies of information systems in the use of technology, Kim and Malhotra (2005) view habit as past behavior. According to Ye and Potter (2011), habit affects future behavior only when the behavior has been accustomed to. Furthermore, he explained that habit formation requires a definite action to be performed frequently and repeatedly. Correspondingly, Venkates et al. (2012) argue that habit is a perceptual construct that reflects the results of previous experience. Several studies have also shown that habits impact technology adoption intentions Nguyen et al. (2014). Habits in the context of using technology will make an adopter continue their intention to use the technology.

\section{RESEARCH METHODS}

Data was collected in mid-2021 in Manado City, Indonesia. Respondents were invited to participate in this study using online social media such as Whatsapp, Facebook, and Instagram. The online survey was developed in Google Form. The sample that participated in this study consisted of 100 participants. The instruments in this study were built from Venkates et al. (2012) research for hedonic motivation, price value, habit, and behavioral intention variables, while the sustainable behavior variable uses instruments from the research of de Kerk and Manuel (2008).

Data were analyzed using path analysis to examine the mediating relationship between variables (Stage et al., 2004). Test necessary reliability instruments in the context of consistency across the parts of a measuring instrument (Taherdoost, 2016).

\section{RESULT AND DISCUSSION}

The image and table of the total path analysis findings show the outcomes of the prior structural equation analysis.

Based on the hypothesis testing results, the variable hedonic motivation $\left(X_{1}\right)$ has a significant relationship with behavior intention $(Z)$. This result can be seen from the significant value of $X_{1}$ to $Z$, which is positive and significant. Then there is a direct influence of hedonistic motivation $\left(X_{1}\right)$ which has a significant relationship with behavior intention $(Z)$.

Based on the hypothesis testing results, the variable price value $\left(X_{2}\right)$ has a significant relationship with behavior intention $(Z)$. This result can be seen from the significant value of $X_{1}$ to $Z$, which is positive and significant. Then there is a direct influence of price value $\left(X_{2}\right)$ which has a significant relationship with behavior intention $(Z)$. Based on the hypothesis testing results, the variable habit $\left(X_{3}\right)$ has a significant relationship with behavior intention $(Z)$. This result can be seen from the significant value of $X_{1}$ to $Z$, which is positive and significant. Then
Table 1: SEM Result

\begin{tabular}{|c|c|c|c|c|}
\hline \multirow[b]{2}{*}{ Variables } & \multicolumn{4}{|l|}{ Effect } \\
\hline & $\begin{array}{l}\text { Path } \\
\text { Coeff }\end{array}$ & Direct & Indirect & Total \\
\hline$X_{1}$ to $\mathrm{Z}$ & 0.164 & 0.164 & - & 0.164 \\
\hline$X_{2}$ to $Z$ & 0.147 & 0.147 & - & 0.147 \\
\hline$X_{3}$ to $Z$ & 0.56 & 0.56 & - & 0.56 \\
\hline$X_{1}$ to $Y$ & 0.189 & 0.189 & $\begin{array}{l}0.164 \times 0.306 \\
=0.050\end{array}$ & 0.239 \\
\hline$X_{2}$ to $Y$ & 0.145 & 0.145 & $\begin{array}{l}0.147 \times 0.306 \\
=0.044\end{array}$ & 0.189 \\
\hline$X_{3}$ to $Y$ & 0.416 & 0.416 & $\begin{array}{l}0,560 \times 0,306 \\
=0,171\end{array}$ & 0.587 \\
\hline$Z$ to $Y$ & 0.306 & 0.306 & - & 0.306 \\
\hline$\epsilon_{1}$ & 0.8 & 0.8 & - & 0.8 \\
\hline$\epsilon_{2}$ & 0.576 & 0.576 & - & 0.576 \\
\hline
\end{tabular}

Source: Data Processed (2021)

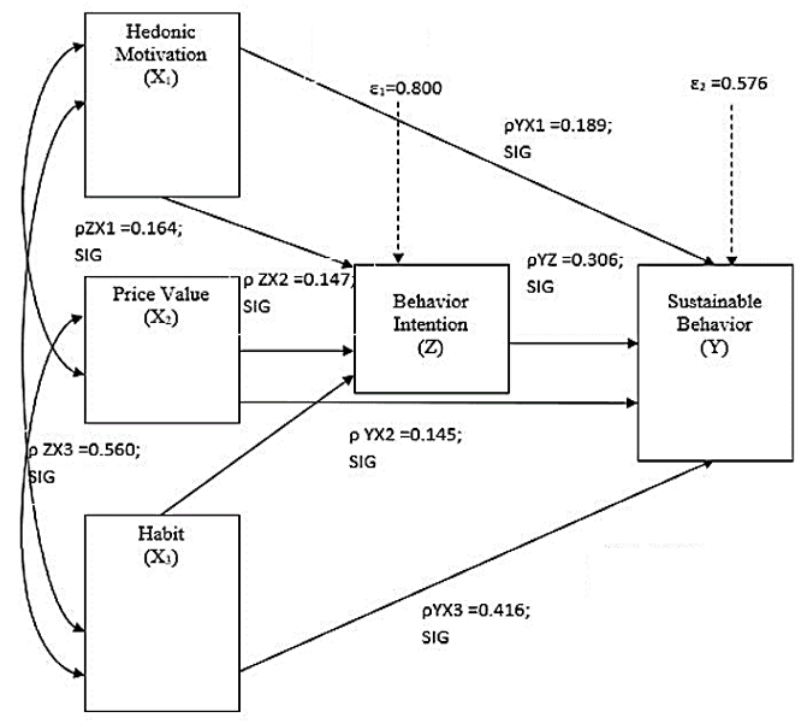

Figure 1: Path Analysis Result 
there is a direct influence of habit $\left(X_{3}\right)$ which has a significant relationship with behavior intention $(Z)$.

Based on the results of hypothesis testing, it shows that the behavior intention $(Z)$ variable has a significant relationship with sustainable behavior $(Y)$. This result can be seen from the significant value of $Z$ to $Y$, which is positive and significant. Then there is a direct influence of behavior intention $(Z)$ which has a significant relationship with sustainable behavior $(Y)$. Based on the results of hypothesis testing, it shows that the hedonic motivation $\left(X_{1}\right)$ variable has a significant relationship with sustainable behavior $(Y)$ mediated by behavior intention $(Z)$. Based on the results of hypothesis testing, the variable price value $\left(X_{1}\right)$ has a significant relationship with sustainable behavior $(Y)$ mediated by behavior intention $(Z)$. Based on the results of hypothesis testing, it shows that the habit variable $\left(X_{3}\right)$ has a significant relationship with sustainable behavior $(Y)$ mediated by behavior intention $(Z)$.

\section{CONCLUSION}

As predicted by this study, hedonic motivation has an impact on technology adoption intentions, as predicted by this study. The findings show that a person's pleasure or satisfaction in using technology will inspire them to adopt it.

Consumers' usage of technology is influenced by expenses and pricing, according to the findings of this study. In the context of consumer users (individuals) and businesses, the value of pricing and costs differ since consumers often face the monetary expenses of adopting technology. A person's intention to accept technology is determined by the availability of a price match (price value).

Furthermore, the findings of the study show that habits have a large and dominant impact on technology adoption. It is simpler for someone to absorb technology if they adopt the behavior that they are used to. Furthermore, habit development necessitates the doing of a certain action on a regular and consistent basis. Habit is a perceptual construct that represents the outcomes of prior experience. As a result, it is simpler for someone who is used to and frequently utilizes technological equipment to adapt the technology.

The findings of this study provide essential contributions, both theoretically and practically, especially in the technology adoption process. The research contribution proves that voluntary consumers' technology adoption behavior, such as hedonic motivation, price value, and habits are essential factors influencing technology adoption intention behavior. This result further strengthens the unified theory of acceptance and use of technology 2 (UTAUT2) model, which focuses on the mechanism of technology adoption by individuals. Furthermore, to improve sustainable behavior in the use of technology, the effect of perceived benefits needs to be reviewed for its role in consumer behavior.

\section{References}

Ajzen, I., 1991. The theory of planned behavior. Organizational Behavior and Human Decision Processes 50 (2).
URL: https://www.sciencedirect.com/science/article/pii/ $074959789190020 \mathrm{~T}$

Akhtar, N., Khan, N., Khan, M. M., Ashraf, S., Hashmi, M. S., Khan, M. M., Hishan, S. S., 2021. Post-COVID 19 Tourism: Will Digital Tourism Replace Mass Tourism? Sustainability 13 (10).

URL: https://doi.org/10.3390/su13105352

Alwahaishi, S., Snasel, V., 2013. Consumers' acceptance use of information and communication technology: A utaut and flow based theoritical model. Journal of Technology Management and Innovation 8 (2), 61-73. URL: https://doi.org/10.4067/S0718-27242013000200005

Arenas-Gaitan, J., Peral-Peral, B., Ramon-Jeronimo, M. A., 2015. Elderly and internet banking: An application of UTAUT2. Journal of Internet Banking and Commerce 20 (1), 1-23.

URL: https://www.researchgate.net/publication/277924056_ Elderly_and_internet_banking_An_application_of_UTAUT2

Aria, R., Archer, N., 2014. Importance of mobile technology in successful adoption and sustainability of a chronic support system. International Journal of Bioengineering and Life Sciences 8 (4), 903-908.

URL: https://doi.org/10.5281/zenodo. 1091730

Babii, A., Nadeem, S., 2021. Tourism in a Post-Pandemic World. International Monetary Fund.

URL: https://www.imf.org/en/News/Articles/2021/02/24/ na022521-how-to-save-travel-and-tourism-in-a-postpandemic-world

Bergin-Seers, S., Mair, J., 2009. Emerging green tourists in Australia: Their behaviours and attitudes. Tourism and Hospitality Research 9 (2), 109-119. URL: https://doi.org/10.1057/thr.2009.5

Bhattacherjee, A., 2001. Understanding Information Systems Continuance: An Expectation-Confirmation Model. MIS Quarterly 25 (3), 351-370. URL: https://doi.org/10.2307/3250921

Brown, S. A., Venkatesh, V., 2005. Model of adoption of technolog y in the household: A baseline model test and extension incorporating household life cycle. MIS Quarterly 29 (3), 399-426.

URL: https://doi.org/10.2307/25148690

Burhanudin, B., Unnithan, A. B., 2021. The determinants of eco-friendly tourist behaviour: Perspectives from Indian and Indonesian tourists travelling abroad. ANATOLIA - An International Journal of Tourism and Hospitality Research, 1-17.

URL: https://doi.org/10.1080/13032917.2021.1905014

Davis, F. D., 1989. Perceived Usefulness, Perceived Ease of Use, and User Acceptance of Information Technology. MIS Quarterly 13 (3), 319-340. URL: https://doi.org/10.2307/249008

de Kerk, G. V., Manuel, A. R., 2008. A Comprehensive index for a sustainable society: The SSI-the Sustainable Society Index. Ecological Economics 66 (2), 228-242.

URL: https://doi.org/10.1016/j.ecolecon. 2008.01.029

Fishbein, M., Ajzen, I., 1972. Attitudes and Normative Beliefs as Factors Influencing Behavioral Intentions. Journal of Personality and Social Psychology 21 (1), 1-9.

URL: http://dx

Fishbein, M., Ajzen, I., 2015. Predicting and Changing Behavior: The Reasoned Action Approach. Psychology Press.

Friedman, T., 2017. Thank You for Being Late: An Optimist's Guide to Thriving in the Age of Acceleration. Farrar, Straus and Giroux.

Gifford, R., 2007. Environmental Psychology and Sustainable Development: Expansion, Maturation, and Challenges. Journal of Social Issues 63 (1), 199-212.

URL: https://doi.org/10.1111/j.1540-4560.2007.00503.x

Gretzel, U., Fuchs, M., Baggio, R., Hoepken, W., Law, R., Neidhardt, J., Pesonen, J., Zanker, M., Xiang, Z., 2020. e-Tourism Beyond COVID-19. A Call For Transformative Research 22 (1), 187-203.

URL: https : //doi .org/10.1007/s40558-020-00181-3

Guerreiro, S., 2019. How global tourism can be more sustainable. Tech. rep. URL: https://www . weforum.org/agenda/2019/09/ global-tourism-sustainable/

Haryanto, T., 2020. Covid-19 Pandemic and International Tourism Demand. Journal of Developing Economies 5 (1), 1-5. URL: https://doi.org/10.20473/jde.v5i1.19767

Jonathan, C. J., Tarigan, R. E., 2016. The Effects of E-Tourism to the Development of Tourism Sector in Indonesia. Communication and Information Technology Journal 10 (2), 59-62.

URL: https://journal.binus.ac.id/index.php/commit/ 
article/view/1669/1419

Kim, S. S., Malhotra, N., 2005. A Longitudinal Model of Continued IS Use: An Integrative View of Four Mechanisms Underlying Post-Adoption Phenomena. Management Science 51 (5), 741-755.

URL: https ://doi .org/10.1287/mnsc.1040.0326

Kostadinova, E., 2016. Sustainable Consumer Behavior: Literature Overview. Economic Alternative 2, 224-234.

URL: https://ideas.repec.org/a/nwe/eajour/ y2016i2p224-234.html

Kotler, P., Bowen, J. T., 2016. Marketing for Hospitality and Tourism (7th ed.). Pearson.

Kurniawan, D. T., Prasasti, A., Rakhmad, A. A. N., Hidayat, W. N., Takada, A., 2021. The Influence of Post Millennial Generation Behavior on Travel Intention to the Ecotourism During the 5th Phase of New Normal or COVID-19 in Indonesia. En: Proceedings of the Sixth Padang International Conference On Economics Education, Economics, Business and Management, Accounting and Entrepreneurship (PICEEBA 2020). Atlantis Press., Paris, France.

Luchs, M., Mooradian, T. A., 2012. Sex, Personality, and Sustainable Consumer Behaviour: Elucidating the Gender Effect. Journal of Consumer Policy 35 (1), 127-144.

URL: https://doi .org/10.1007/s10603-011-9179-0

Mihanyar, P., Aminudin, N., Rahman, S. A., 2015. The Influence of Sustainable Tourism Awareness and Environmental Sustainability Dimensions on Behavioural Intentions Among Domestic Tourists in Developing Countries. Tropical Tourism Outlook Conference 2.

Nanggong, A., 2018. Perilaku Pasca-Adopsi Teknologi Personal terhadap Intensi Perilaku Berkelanjutan. Jurnal Manajemen Teknologi 17 (1), 10-26. URL: https ://doi.org/10.12695/jmt.2018.17.1.2

Nanggong, A., Rahmatia, R., 2019. Perceived Benefit, Environmental Concern and Sustainable Customer Behavior on Technology Adoption. The Asian Journal of Technology Management 12 (1), 31-47.

URL: https://doi.org/10.12695/ajtm.2019.12.1.3

Nelson, K. M., Partelow, S., Stabler, M., Graci, S., Fujitani, M., 2021. Tourist willingness to pay for local green hotel certification. Plos One 16 (2), 1-19. URL: https://doi.org/10.1371/journal .pone.0245953

Nguyen, T. D., Nguyen, D. T., Cao, T. H., 2014. Acceptance and Use of Information System: E-Learning Based on Cloud Computing in Vietnam. Information and Communication Technology, 139-149.

URL: https : //www.researchgate.net/publication/278700656
DOI: $10.1007 / 978-3-642-55032-4{ }_{1} 4$

Nugraheni, B. D., Nurhaeni, I., 2018. Implication of E-Tourism on Culture Value of Community Based Tourism in Indonesia. Conference: 2018 Annual Conference of Asian Association for Public Administration: "Reinventing Public Administration in a Globalized World: A Non-Western Perspective" (AAPA 2018), 1-11.

URL: https ://doi.org/10.2991/aapa-18.2018.1

Stage, F. K., Carter, H. C., Nora, A., 2004. Path Analysis: An Introduction and Analysis of a Decade of Research. The Journal of Educational Research 98 (1), 5-13.

URL: https : //doi .org/10.3200/JOER.98.1.5-13

Taherdoost, H., 2016. Validity and Reliability ofthe Research Instrument; How to Test the Validation of a Questionnaire/Surveyin aResearch. International Journal of Academic Research in Management 5 (3), 28-36.

URL: https : //doi .org/10.2139/ssrn. 3205040

Tapia Fonllem, C., Corral-Verdugo, V., Fraijo-Sing, B., Duron-Ramos, M. F., 2013. Assessing Sustainable Behavior and its Correlates: A Measure of ProEcological, Frugal, Altruistic and Equitable Actions. Sustainability 5 (1), 711-723.

URL: https : //doi .org/10.3390/su5020711

UNWTO, 2021. Statistical Annex World Tourism.

URL: https://www.wto.org/english/tratop_e/envir_e/unwto_ barom 21 .pdf

Venkates, C. K., Tyagi, M., Ganesh, L., 2012. Fundamental analysis and stock returns: An Indian evidence. Global Advanced Research Journal of Economics, Accounting and Finance 1 (2), 33-39. URL: http://garj .org/garjb/index.htm

Venkatesh, V., Morris, M. G., Davis, G. B., Davis, F. D., 2003. User acceptance of information technology: Toward a unified view. MIS Quarterly 27 (3), 425-478.

URL: https : //doi.org/10.2307/30036540

Ye, C., Potter, R. E., 2011. The Role of Habit in Post-Adoption Switching of Personal Information Technologies: An Empirical Investigation. Communications of the Association for Information Systems 28 (1), 1-10. URL: https : //doi .org/10.17705/1CAIS . 02835

Zhang, J., 2009. Tourism e-commence business model innovation analysis. En: International Conference on E-Business and Information System Security, EBISS. IEEE.

URL: https ://ieeexplore. ieee.org/document/5138137 